\title{
$\underline{\text { Recent Work in Victorian Studies and the Bildungsroman }}$
}

Sara Lyons

University of Kent

Abstract: This article evaluates recent work in Victorian Studies on the Bildungsroman, with particular attention to how scholars negotiate the legacy of Franco Moretti's bravura reading of the form, The Way of the World: The Bildungsroman in European Culture (1987). It concludes by suggesting that Georg Lukács' discussion of the 'Novel of Disillusionment' in his Theory of the Novel (19145 ) offers a means of moving beyond the critical impasse that the bildungsroman has come to represent.

It is by now a convention for critics to approach the question of the bildungsroman with confessions of anxiety or weariness. It is one of the most controversial terms in literary study, afflicted by both promiscuous and precious definitions, and the challenge of summarising the existing scholarship is too much for the introductory chapter of many monographs devoted to the topic, let alone to be dispatched easily in a paragraph or footnote by the scholar who only wants to address it in passing. Likewise, critical debate over its meaning is at once extremely narrow - focussed on the conclusions of a handful of canonical novels - and freighted with high stakes, since the form is often taken to be coextensive with the history of literary realism, the history of the novel, the history of aesthetics, the history of Romanticism, or, as a recent critic puts it, 'the humanist origin story of culture' (Feder, 2014, p. 19). Some of the contention is traceable to the indeterminacy of the German word bildung, which is translated into English variously as 'development', 'education', 'apprenticeship', 'self-culture', 'acculturation', or 'formation', and generates controversy about the extent to which the phenomenon must be understood in the context of the German literary tradition or German idealist philosophy, or even more exclusively in relation to the archetypal bildungsroman, Johann Wolfgang von Goethe's Wilhelm Meister's Apprenticeship (1795-6). The seemingly irresistible appeal of this generic category to Anglophone literary scholars arises from the suggestion, first made by Wilhelm Dilthey, that it fuses form and ideology with a sense of organic inevitability. In a 1906 collection of essays, Poetry and Experience, Dilthey claimed that the genre depicts an introspective youth who

enters life in a happy state of naivete [but] comes into conflict with the hard realities of the world [... and] grows to maturity through diverse life experiences [....] A lawlike development is discerned in the individual life; each of its levels has intrinsic value and is at the same time the basis for a higher level. Life's dissonances and conflicts appear as necessary transitions to be withstood by the individual on his way towards maturity and harmony. (pp. 335-336) 
The classic bildungsroman is thus often read as a conservative fable of socialisation: the Romantic youth progressively adjusts his or her desires for freedom and creative fulfilment to the demands of society, and this process is sanctified as the attainment of maturity. Such novels make social conformity appear profoundly seductive precisely because they acknowledge its ambivalent character: in Georg Lukács' words (1971), they make seem 'the fruit of a rich and enriching resignation, the crowning of a process of education; a maturity attained by struggle and effort' (p. 133). What is more, the form imposes a sense of aesthetic necessity upon this process: the mistakes and illusions of the hero or heroine are all ultimately turned to account and harmonised into self-mastery, so that the resolution of plot and character development form a pleasing whole. At the level of allegory, the apparent conflicts between poetic ideals and social reality, individual and the state, are dialectically resolved, with the protagonist coming to recognise his or her desires can be fulfilled most truly through custom and dutiful citizenship. To quote Lukács again, the bildungsroman thereby makes social convention appear not a rigid set of rules but an organic phenomenon, 'partially open to penetration by living meaning' (p. 137).

The fact that very few novels actually follow this pattern - and that it does not do justice even to Wilhelm Meister - has not deterred critics from identifying the bildungsroman as a form defined by a coercive sense of teleology and normativity, and from scrutinising virtually all novels for the degree to which they rebel against the alleged tyranny of its logic. This has in turn led Marc Redfield (1996) to debunk the bildungsroman as a 'phantom formation', a spectre conjured by the contradictions of Romanticism's 'aesthetic ideology' and the fantasies of literary critics (p. 63). Yet even Redfield's forbidding deconstructive reading has failed to stem the tide of new monographs and essays on the subject. This is not simply evidence of scholarly perversity. Critics are reluctant to give up the generic ideal of the bildungsroman because it grants them a clear charter for analysing aesthetics and politics simultaneously; in particular, as Tobias Boes (2006) has pointed out, it has furnished critics with a framework for reading a large body of feminist, postcolonial, and ethnic coming-of-age novels in terms both of political resistance and formal experiment. The impulse to return to the problem of the bildungsroman among Anglophone literary critics is also surely because the most influential modern reading of the form, Franco Moretti's The Way of the World: the Bildungsroman in European Culture (1987), is at once so exhilarating and disappointing for them: it exalts the Continental bildungsroman as the most exemplary and politically telling form of modern literature, ignores the American tradition altogether, and treats the English novel with open contempt, calling it 'the worst novel of the West' ( p. 214).

Moretti anoints the European bildungsroman as the 'symbolic form of modernity' (p. 5); to read it is to grasp how bourgeois subjectivity legitimates itself to itself through artfully calibrated compromises. In Moretti's memorable formulation, the protagonist's gradual accommodation of his quixotic ideals to the ways of the world allegorises 'how the French Revolution could have been avoided' (p. 64). In his readings of French and German novels, the conservatism of the bildungsroman always seems intelligent and never facile; even if a somewhat evasive compromise with capitalism is their final destination, bildungsromane by Goethe, Honoré de 
Balzac, Gustave Flaubert, and Stendhal reckon honestly with the dilemmas of modernity. Not so with the English novel: where the Continental protagonist comes to terms with the contradictions of modern life, the English protagonist pretends modernity has not happened and sees no point in growing up. Sparing only George Eliot's novels, Moretti dismisses the English bildungsroman as a species of children's literature: it offers not a narrative of initiation but a fantasy of regression; its heroes and heroines are impervious simpletons, embodying a Manichean view of morality and a complacent national politics.

Anglophone literary critics could hardly rest content with this assessment: Moretti suggests that the English bildungsroman is so morally and politically vacuous that it is scarcely worth reading, let alone analysing (he is mainly slighting Charlotte Brontë's Jane Eyre [1847] and Charles Dickens' novels). Even if a critic is more interested in ideology critique than in defending the artistic worth of the English novel, Moretti's account is likely to be constraining, since he makes nineteenthcentury English society, or at least the version of it deducible from the novel, seem virtually feudal in its inertia. (Somewhat contradictorily, however, he also suggests that the vapid protagonists of the English bildungsroman reflect a more democratic and therefore presumably more modern national ethos than is manifest in Continental examples of the form [pp. 189-192].) The one interesting feature that Moretti grants the English bildungsroman is its preoccupation with legalistic conceptions of justice, reflected in the prominence of court room scenes, accusations, interrogations, and forms of testimony within its pages, but this too he understands as a manifestation of its fairytale moralism (p. 213). Moretti also proclaims that the age of the bildungsroman exhausts itself with Eliot, thereby excluding many commonly read and taught late nineteenth-century novels from consideration under its aegis (pp. 223-28).

In recent critical work on the Victorian bildungsroman, Moretti's Way of the World remains the authoritative book that everyone cites, and most critics proceed by attempting to refine or contest its arguments. In what follows, I consider the extent to which recent criticism has succeeded in complicating Moretti's account of the Victorian bildungsroman, and conclude with my own proposal for how we might move beyond it.

\section{Beautiful Souls: Religion, Morality, and Aestheticism}

Although Moretti does not say so explicitly, his complaints about the fairytale logic and moral absolutism of the English bildungsroman might be understood as an aversion to the more conspicuous presence of religion, or at least religious morality, in it than in the Continental tradition. Kelsey L. Bennett's Principle and Propensity: Experience and Religion in the Nineteenth-Century British and American Bildungsroman (2014) makes the case for the centrality of religion to the bildungsroman tradition and reads Brontë's Jane Eyre, Dickens's David Copperfield (1850), Henry James's The Portrait of a Lady (1881), and Herman Melville's Pierre (1852) in relation to Protestant theological traditions, specifically the legacies of John Wesley and Jonathan Edwards. Bennett traces the connections between English and American Evangelical movements and German Pietism, and highlights the presence of Count Nikolaus 
Zizendorf and the Moravian Church in Wilhelm Meister. She suggests that nineteenth-century bildungsromane grapple with theological questions about human agency, divine will, and salvation that animated the Evangelical Revival in England and the Great Awakening in the United States, and this provides the rationale for examining the form as the product of transatlantic Protestant culture. Her broad distinction between Arminian and antinomian strains in nineteenth-century religious thinking - in her construal, the first grants greater scope to human will and good works, while the second has a Calvinist emphasis upon human impotence and the world's depravity - is a suggestive framework for interpreting the bildungsroman, since it maps onto oppositions between world and self, action and reflection, which are commonly understood as the dialectical motors of the form.

Although Bennett seeks to correct the tendency of scholars, including Moretti, to treat the bildungsroman as an essentially secular phenomenon, her efforts to delineate its religious character actually tend to legitimate secular interpretations: while it is true that the concept of bildung has theological roots, her readings consistently reveal the extent to which the bildungsroman posits religious commitments as something to be renounced or incorporated into a more expansive, secular vision. Her book thus demonstrates not the vitality of religion so much as the significance of its symbolic marginalisation in the bildungsroman, and I often wished that she had analysed the implications of the form's secularising drive more directly. Nonetheless, her book illuminates the extent to which nineteenth-century bildungsroman are faithful to the example of Wilhelm Meister insofar as they grant serious consideration to the idea of the 'Beautiful Soul'. Book 6 of Wilhelm Meister includes the interpolated 'Confessions' of a woman who withdraws from aristocratic society into a life of religious asceticism. As Bennett notes, the status of the 'Confessions' in the context of the novel as a whole is ambiguous: it is not clear if Goethe ennobles or pathologises her intense religiosity, though it evidently represents a form of otherworldliness that is untenable for the novel's hero. In part because of the tendency to read it through the prism of G. W. F. Hegel's discussions of the Beautiful Soul theme, the 'Confessions' is often taken as a critique of a solipsistic personality type, one who attempts to protect his or her sense of inner perfection by turning away from the world but who thereby only impoverishes his or her own humanity. In Phenomenology of Spirit (1807), Hegel writes that 'Beautiful Soul 'lives in dread of besmirching the splendour of its inner being by action and an existence; and, in order to preserve the purity of its heart, it flees from contact from the actual world, and persists in its self-willed impotence'(1977, p. 400).

Bennett is preoccupied with the Pietistic dimensions of the 'Confessions' and with specific tenets of Protestant theology in her chosen novels, and she does not pose the question her study seems to provoke: why is religious asceticism so often accorded a privileged, but ultimately marginal, role in the bildungsroman? Why, in Jane Eyre, is it constructed as a temptation to be resisted, one that poses an equal or perhaps greater threat to the heroine's soul than illicit sexuality? Bennett does not make this point explicitly, but the powerful allure that varieties of asceticism and quietism - both religious and secularised - hold for the protagonists of bildungsromane by Eliot, James, Thomas Hardy, and Walter Pater, attest to the persistence of the 'Beautiful Soul' theme in Anglo-American renderings of the form. 
This persistence in turn suggests a more philosophically serious form of ambivalence toward modernity than the mere fetishisation of naivety that Moretti detected in the English bildungsroman. The 'Beautiful Soul' theme may in fact represent a critical thread running from Goethe's Wilhelm Meister and Hegel's philosophy through nineteenth-century and modernist bildungsromane. As Drew Milne (2002) has suggested, Hegel's analysis of the 'Beautiful Soul' archetype resonates with the ethical and political equivocations of modernist art as well as with the modernist ideal of the artist, who similarly embodies a 'dissident delicacy' and 'inwardly determined [...] secular saintliness' (p. 64). Goethe's and Hegel's treatment of the Beautiful Soul theme are equally suggestive reference points for analysing how nineteenth-century bildungsromane such as Middlemarch (1871), Roderick Hudson (1875), Daniel Deronda (1876), Portrait of a Lady, and Jude the Obscure (1895) explore the attractions and dangers of moral or religious idealism in the modern world.

In the Oxford Handbook to the Victorian Novel (2013), Julia Prewitt Brown's essay on the bildungsroman accepts Moretti's claim that the English bildungsroman is distinguished by its moralism and fairytale elements, but unlike him, she treats these features as a mark of complexity. Drawing on Walter Benjamin, she reads the didactic impulse of the English bildungsroman as a residue of its archaic origins in myth and fairytale, and gives a compelling account of how their mixture of realism and fantasy destabilises their efforts to rationalise the modern social order. In particular, she draws a distinction between the 'novel of accountability' and the 'novel of empowerment'. The first category of bildungsromane, in which she places Jane Austen's Emma (1815) and Dickens's Great Expectations (1861), pivots on the protagonist's coming to terms with his or her sense of moral responsibility for a single dramatic event, and tends to be grounded more fully in social realism. The second category, in which she places Jane Eyre and David Copperfield, is preoccupied with the protagonist's quest for social status, and is more clearly indebted to fairytale structures. Prewitt Brown also addresses the common perception that the fairytale aggrandisement of the hero or heroine in the latter type of bildungsroman has ugly moral and political implications. In response, she mounts a vigorous defence of the 'ethical integrity' of David Copperfield and Jane Eyre, attempting to demonstrate that when readers detect hypocrisy or aggression in the protagonists, they are reacting not to the political unconscious of these novels but to Brontë's and Dickens' subtlety as moral psychologists.

Jesse Rosenthal's Good Form: The Ethical Experience of the Victorian Novel (2017) also mounts a defence of the moralistic tendencies of the English bildungsroman. His reading of the form is grounded in his wider effort to recuperate the Victorian tradition of moral intuitionism, the view that there are objective moral truths and that we share an innate capacity to apprehend them directly. Rosenthal argues that utilitarianism has held too much sway in our understanding of Victorian conceptions of morality as well as in our interpretation of the Victorian novel, and that due attention to the age's rival philosophy, intuitionism - associated with figures such as William Whewell and H. L. Mansell - casts light on the narrative effects of Victorian novels as well as Victorian aesthetic theory. He simultaneously seeks to clarify how moral intuitionism covertly shapes modern literary criticism. 
Although Rosenthal denies that he wishes to vindicate moral intuitionism as a philosophy, his adoption of it as an interpretive framework amounts to an at least partial endorsement, and it has distinctive consequences for his reading of the bildungsroman. He accepts the view that the bildungsroman has a disciplinary, normative drive but grants that drive more intellectual dignity than has been customary among modern critics of the form. In his account, the hero or heroine's ultimate integration into the social order should be appreciated as a complex act of reinterpretation: he or she comes to recognise that his or her desires were always thoroughly social, part of a sensus communis or shared understanding, and thus to embrace the communal good is not merely to sacrifice one's individual desires to the collective but to grasp their true, socially mediated nature. In other words, where modern critics have generally been suspicious of how the bildungsroman strives to reconcile the individual to the given order of things, Rosenthal attempts to explain why this dialectical resolution is aesthetically satisfying. At the same time, he argues that the conventional bildung plot attempts to resolve the problem of free will in a manner akin to Immanuel Kant's somewhat mystifying solution: Dickens's Pip in Great Expectations (1861) and John Stuart Mill in his Autobiography (1873) arrive at a sense of freedom retrospectively, by recognising that they have always already made a moral choice; although a given choice in the present appears to be determined by the iron chain of causality, the protagonist recognises that he or she chose a prior link in the chain. Rosenthal then extends these arguments to the perspective of the reader: her pleasure in the narrative derives from this reconciliation of character freedom and the determinism of plot. Further, we do not need to feel ashamed of the narrowness or seeming arbitrariness of the modern canon of Victorian novels (many of which are bildungsroman) because the modern reader repeats the same journey as the bildung protagonist: finding an apparently individualistic pleasure in Jane Eyre or David Copperfield, he or she fact realises the capacity to participate in a wellestablished sensus communis.

Rosenthal's argument, which is too intricate to do full justice here, does not really counter Moretti's charge that the English bildungsroman is a complacent fairytale genre and that the English protagonist is essentially regressive, venturing into the world only to affirm the plenitude of his or her childhood feelings. Nor does Rosenthal try to contest Moretti's argument that such bildung plots encode a conservative or liberal/reformist politics, and that the ultimate containment of the hero or heroine's rebellious energies symbolically serves to contain the threat of political revolution. Moral intuitionism is often understood to be an intrinsically conservative philosophy, and it is somewhat frustrating that Rosenthal never clarifies whether he considers it so. In this context, his choice of Mill's autobiography as an exemplary bildungsroman seems provocative: as Rosenthal himself notes, Mill's antipathy toward moral intuitionism was as much moral and political as it was logical, grounded in his conviction that it served to place superstition and prejudice beyond the reach of rational critique. Rosenthal's book as a whole is an intriguing experiment in trying to read with the grain of an imagined Victorian-yet-alsocontemporary common reader, whose moral feelings and taste for what are often considered 'low' aesthetic pleasures - jokes, suspense, happy endings, readability - are shown to have real philosophical depth. Yet the discussion of Mill inevitably 
calls to mind the political tensions that are being neutralised by the projection of this Victorian/modern sensus communis of pleasure-driven readers: Mill would not doubt find the bildungsroman logic described by Rosenthal maddening rather than aesthetically pleasurable, precisely because it rests on unfalsifiable appeals to gut feeling, or quasi-mystical appeals to the past. Given Rosenthal's emphasis on what feels right to the reader and his suggestion that moral intuitionism is a secret undercurrent in modern literary criticism, it is also odd that he does not address the fact that the endings of bildungsromane such as Jane Eyre and David Copperfield have often felt very wrong, both morally and aesthetically, to contemporary literary critics: as Prewitt Brown's essay addresses in depth, it is a critical cliché that their resolutions aim to reconcile us to a form of injustice or oppression, and are thus found improbable or disturbing. It may be that this particular sensus communis is in the process of breaking down: Good Form exemplifies the recent critical desire to relax the hermeneutics of suspicion and explore more hedonistic and affirmative ways of reading.

In his introduction, Rosenthal expresses doubt that literature has the transformative power that literary critics have often ascribed to it. Yet he seems more relieved than anxious about the possibility that literature makes nothing happen: it liberates the critic to explore other questions (p. 6). Elisha Cohn's Still Life: Suspended Development in the Victorian Novel (2015) also articulates a certain exhaustion with the obligation to make large claims for the political stakes of reading Victorian literature (pp. 184-194). Fatigue, and the wish to hibernate from worldly commitments and activities, are also the subjects of her book, though she does not explicitly address the connection between the 'Beautiful Soul' theme and the bildungsroman. According to Cohn, the Victorian bildungsroman is punctuated by lapses - lyric moments of languor, distraction, or passivity - that postpone the developmental trajectory of the plot. Where a previous generation of critics might have claimed that such interruptions are moments of political subversion or critique, or at least that they show some glimmer of utopian possibility, Cohn insists that they have no purpose beyond themselves.

'Aestheticism' is the final word of Cohn's book and throughout it appears to be her real subject. Yet her chosen writers - Charlotte Brontë, Eliot, George Meredith, and Hardy - are not conventionally associated with aestheticism or decadence, and Cohn oddly suppresses the fact that there was a Victorian literary and artistic movement dedicated to exploring the unproductive states of being that interest her. The extent to which novels by Brontë, Eliot, Meredith, and Hardy can read like works of decadent aestheticism, at least in certain passages, is beautifully revealed in her close readings, and perhaps she felt it was too obvious a point to spell out: the book is remarkable for its erudition and subtlety. Nonetheless, her overall argument depends upon an identification of the bildungsroman with the strenuousness of high Victorian ideology: the gospel of work, the self-surveillance and perfectionism of the Protestant conscience, the 'progress' of capitalism and empire. Some acknowledgment of aestheticism and decadence might have complicated this characterisation of the meaning of bildung in Victorian culture.

Cohn's account of Victorian bildung collapses two concepts that Gregory Castle's Reading the Modernist Bildungsroman (2006) usefully prises apart. Castle 
suggests first that there are two distinct traditions of bildung within German Romanticism: the first, associated with Goethe, was more mystical, elitist, and invested in the arts as a touchstone for self-cultivation; the second, associated with Wilhelm von Humboldt, was more practical, democratically minded, and preoccupied with education as a mechanism of personal development (pp. 34-47). Castle then posits a further split: the nineteenth century rationalised and bureaucratised the Romantic ideals of self-development and inner culture, and Victorian writers produce a 'socially pragmatic' bildung, which essentially works to manufacture consent to bourgeois social norms (pp. 47-62). This sets the stage for modernists to rediscover the radical potential latent in the 'aesthetico-spiritual' tradition: its ideals of creative autonomy and self-cultivation can be reclaimed (though only to be subjected to a negative dialectics that Castle understands as the signature of modernist art). Although he pays careful attention to Mill and Thomas Carlyle as proponents of bildung and treats Hardy's Jude the Obscure and Oscar Wilde's A Picture of Dorian Gray (1890) as honorary modernist texts, Victorian literature fares little better in Castle's account of the bildungsroman than it does in Moretti's: it is the dull bourgeois way station between the bohemian adventures of Romanticism and modernism. Nonetheless, critics of Victorian literature can adopt his taxonomy of the different varieties of bildung without fully accepting his sense of a sharp Victorian/modernist divide.

Castle's distinction between the socially pragmatic and aesthetico-spiritual traditions of bildung might have enabled Cohn to perceive the critical and creative potential of the bildungsroman rather than treat it simply as a formalisation of social norms. Cohn resists ascribing any purpose or clear value to the 'lyric' moments she dwells on in Brontë, Eliot, Hardy, and Meredith because she fears to do so is to succumb to the oppressive logic of socially pragmatic bildung. Such passages might be placed within the aesthetico-spiritual tradition of bildung, and would seem to attest to the fact that this tradition had continued vitality in Victorian culture. The literature we associate with aestheticism and decadence is another more obvious tributary of this tradition, and indeed, Andrew Eastham has anatomised how Pater, James, and Wilde negotiate the legacy of Romantic bildung in his Aesthetic Afterlives: Irony, Literary Modernity, and the Ends of Beauty (2011).

\section{The Shadow Bildungsroman: Victorian Science and Psychology}

Cohn's Still Life also exemplifies the growing critical impetus to reappraise the bildungsroman in the light of nineteenth-century scientific materialism and physiological psychology. As her book and recent articles by Jill Ehnenn (2017), Natalie Huffels (2011), Elisabeth Jay (2010), and Anna-Julia Zwierlein (2012) clarify, a large body of Victorian scientific theory undermined the Enlightenment optimism upon which the ideal of bildung was founded. Although this is not an explicit aim of Cohn's book or any of the aforementioned articles, this new critical focus on how the Victorian bildungsroman engages with contemporary scientific and psychological speculation also helps to complicate the cliche that the modernist bildungsroman undermined a sanguine Victorian belief in the unity and transparency of the self. Such work simultaneously challenges Moretti's claim that the classical bildungsroman 
became impossible after Eliot because its vision of a unified, rationally fulfilled personality was incompatible with the emergence of modern psychology. As Cohn's book explores in relation to Brontë, Eliot, Hardy, and Meredith, and as Huffels's article shows in relation to Wilkie Collins's The Woman in White (1859), many major Victorian novelists were inspired by new psychological theories which put Enlightenment rationalism into question. As a result, they produce bildungsroman which represent the mind as embodied, unreliable, and often opaque to itself.

Huffels's article, the winner of Victorian Review's annual graduate essay prize, argues that The Woman in White draws upon theories of shock, memory, and double consciousness to construct a 'shadow-bildungsroman', one which underscores the impossibility of developing an integrated selfhood in the wake of psychic trauma. Meanwhile, Jay examines how Eliot's The Mill on the Floss and Hardy's Jude the Obscure respond to the secularisation of memory: where the Christian tradition endowed memory with ethical and metaphysical value, Victorian science and psychology demystified it as a physiological reflex. Zwierlein anatomises the impact of a wide range of nineteenth-century scientific and psychological paradigms upon Victorian renderings of the bildungsroman, including anthropometry, physiological models of habit formation and theories of organic memory, heredity, and degeneration. Focussing on the representation of social class and embodiment in Oliver Twist (1838), David Copperfield, and Jude the Obscure, she examines how Victorian scientific theories cast doubt on liberal ideals of rational autonomy and self-improvement, while also seeming to render class identity a matter of biological destiny. Ehnenn also casts fresh light on the interplay between eugenics, degeneration theory, and the tendency of the Victorian bildungsroman to 'enforce normalcy' (p. 152). She reads Lucas Malet's The History of Sir Richard Calmady (1901) and Hardy's Jude the Obscure through the lenses of queer and disability studies, suggesting that both novels challenge the social stigma attached to non-normative bodies and desires.

Ehnenn's and Zwierlein's shared interest in late Victorian eugenicist thought leads them both to dwell on the representation of minor characters in the bildungsroman. Both note that minor characters tend to lack psychological depth and to be defined by their physiological traits, and that this caricatural status serves to create the exceptional humanity of the protagonist. Neither Ehnenn nor Zwierlein engage directly with Alex Woloch's The One vs. the Many: Minor Characters and the Space of the Protagonist in the Novel (2009), but their comments on the subject are a useful supplement to his reflections on how nineteenth-century novelists used the distinction between a novel's protagonist and its minor characters to think through the problematics of democracy.

\section{The Prose of Circumstances: Education, Work, and Democratic Politics}

As noted, Moretti claims that the banality of the English bildungsroman is a product of its democratic spirit: breaking with the desire to emulate aristocratic culture more fully than the Continental version, it celebrates stolid virtues like plainness, sincerity, and ordinariness (pp. 181-228). Castle ventures a similar argument, linking mid-century liberalism and the extension of educational opportunities in Victorian 
England to the rise of a utilitarian bildung, oriented toward institutions and social mobility rather than more nebulous ideals of inwardness and aesthetic development (pp. 45-57).

Richard Salmon (2013) accords a central place to the bildungsroman in his study of the professionalisation of literature in the nineteenth century. He affirms the view that the English bildungsroman is more prosaic and preoccupied with work than the European version, but he richly contextualises this point by situating it in relation to the material realities of authorship and developing ideals of the literary profession. In particular, he demonstrates that Victorian writers turned to the bildungsroman in order to at once think through and subtly polemicise on behalf of what he calls the 'disenchantment of the author' - the transition from Romantic notions of genius to the more mundane yet still prestigious ideal of the professional writer (pp. 8-16). Although he devotes a requisite chapter to David Copperfield as a canonical bildungsroman, the compelling force of his argument derives from the extent to which he has recovered a half-forgotten literary history: he focusses on Edward Bulwer-Lytton's Ernest Maltravers (1837) and Alice: Or, the Mysteries (1838), Benjamin Disraeli's Contarini Fleming (1832), G. H. Lewes' Ranthorpe (1847), and W. M. Thackeray's History of Pendennis (1848-50), and on the complex debate among these writers about the nature of the literary vocation, which was conducted both via the bildungsroman and in the periodical press. Salmon shows that the more pragmatic focus of the English bildungsroman is not an effect of mere philistinism - as he documents, English authors were often highly conscious of Wilhelm Meister as a model and of the German Romantic tradition more generally - but of a desire to construct realistic narratives of literary apprenticeship. He also emphasises the selfreflexivity and dialectical sophistication of the English bildungsroman, which attempts to retain some of the glamour of the Romantic vision of the artist even as it exposes that ideal to the exigencies of the marketplace.

Christiane Gannon's $(2014,2015)$ two articles on the Victorian bildungsroman also emphasise its pragmatic sensibility, but she argues that in the cases of the writers she examines - Walter Besant and Wells - this is paradoxically rooted in political idealism: it is an effect of their efforts to render the form amenable to democratic and socialist principles. Gannon delineates a late nineteenth- and early twentieth-century tradition of linking aesthetic education to egalitarian ideals, and suggests that Besant's All Sorts and Conditions of Men (1882) and Wells' The Bulpington of Blup (1932) are attempts to incarnate this philosophy in the bildungsroman. Both essays are efforts to reappraise little read (and when read, generally disparaged) novels, and Gannon makes an interesting case for how some of their indigestible features can be appreciated as part of a coherent political project. (I include her article on Wells' 1932 novel not only because, as she notes, Wells tends to be treated as a Victorian rather than a modernist writer, but because much of her analysis of The Bulpington of Blup is relevant to his earlier comic bildungsromane, Love and Mr. Lewisham [1900], Kipps [1905], and The History of Mr. Polly [1910], and may be of interest to Victorianist scholars of the genre). Gannon's articles appear to be previews of a welcome monograph which would use the bildungsroman and the tradition of democratic idealism to bridge the divide between Victorian and modernist literature. 
Anna Bogen's Women's University Fiction, 1880-1945 (2013) concentrates mainly on novels published after the Victorian period, but it argues that the bildungsroman provided a crucial template for the representation of women's experiences of university life from the late Victorian period onwards. Bogen interrogates the critical commonplace that the bildungsroman is an inhospitable genre for both women writers and women protagonists because it presupposes modes of freedom and education from which women have been traditionally debarred. Her analysis of a large body of forgotten popular and 'middlebrow' university novels by women writers or featuring women protagonists suggests that the bildungsroman was in fact an appealing genre for writers precisely because of its capacity to capture the dissonances between romantic ideals and social experience. Her book also offers a useful overview of the phenomenon of the university novel, which she regards as a subgenre of the bildungsroman, and insight into how Oxford and Cambridge universities served to institutionalise ideals of bildung in Britain.

\section{Colonial Coming of Age}

Although it bills itself as a book about literary modernism, Jed Etsy's Unseasonable Youth: Modernism, Colonialism, and the Fiction of Development (2011) is equally, or perhaps more, significant as a contribution to Victorian studies: the majority of bildungsromane under consideration are Victorian or Edwardian (Eliot's Mill on the Floss, Olive Schreiner's Story of an African Farm [1883], Wilde's Picture of Dorian Gray, Rudyard Kipling's Kim [1901], Wells's Tono-Bungay [1909], and Joseph Conrad's Lord Jim [1900]). Etsy seeks to extend the political reach of Moretti's Way of the World by arguing that the classical bildungsroman was a means of allegorising Romantic nationalism, with the harmonious maturation of the protagonist doubling as a wishfulfilment of nationalist aspirations. According to Etsy, the plausibility of such organicist allegories began to fragment under the contradictions of colonialism, producing modernism's distinctive narratives of failure, regression, and stagnation - though as noted, he discovers such 'modernist' innovation in a considerable number of Victorian novels. What Moretti takes to be the static fairytale innocence of the English bildungsroman protagonist, Etsy suggests is a more politically and aesthetically interesting condition of arrested development. His book sustains a high level of theoretical sophistication throughout while offering inspired readings of his chosen novels, and he persuasively reveals the ideological density of the trope of 'unseasonable youth' in the representation of colonialism. Yet a certain tension is produced by his effort to bring some of the insights of work on the postcolonial bildungsroman to bear on reading the representation of colonialism in Victorian and early twentieth-century novels. It is commonly observed that, as Jopi Nyman (2009) puts it, ' post-colonial uses of the bildungsroman are counterdiscursive and write against the idealised notion of the autonomous individual imagined in canonised European classics from Goethe to Dickens' (p. 94). All of Etsy's chosen writers are of white European descent and most could, to varying and complicated degrees, be considered beneficiaries or agents of colonialism, rather than victims of it; yet the logic of his argument is to transfer the counterdiscursive prerogative now conventionally associated with the postcolonial bildungsroman (as well as with 
feminist handlings of the form) to them. His analysis attends to these complexities judiciously, but his over-arching emphasis on how the trope of failed or thwarted bildung transcends the coloniser/colonised binary has the uneasy effect of implying that colonialism blighted all youthful potential indifferently, rather than facilitating the flourishing of some at the cost of others.

Mandy Treagus's Empire Girls: The Colonial Heroine Comes of Age (2010) reckons with the question of colonial guilt and complicity more directly. It gives extended attention to three bildungsromane by Victorian or Edwardian 'New Women' from different outposts of the British empire - Schreiner's Story of an African Farm (South Africa), Sara Jeannette Duncan's A Daughter of Today (1894, Canada), and Henry Handel Richardson's The Getting of Wisdom (Ethel Richardson, 1910, Australia). Treagus understands the Victorian bildungsroman as complicit in colonialism at least insofar as it purveyed a myth of meritocracy that was covertly reliant on imperial expansion. Her book is simultaneously a contribution to the now considerable body of scholarship which considers how the premise of a female protagonist disrupts the generic conventions of the bildungsroman. Her analysis focusses on how Schreiner, Duncan, and Handel Richardson struggle with a sense of double marginality as women and as writers on the colonial periphery, and traces how they by turns confront and evade the links between colonial and patriarchal power.

Tobias Boes' work of comparative criticism, Formative Fictions: Nationalism, Cosmopolitanism and the Bildungsroman (2012), concentrates mostly on the German literary tradition but includes a chapter on Eliot's Daniel Deronda (1876) and its overall argument has important consequences for future work on questions of empire, nation, and the Anglophone bildungsroman. Like Etsy and Treagus, Boes sees the bildungsroman as entangled with the rise of modern nationalism, but he emphasises that the identification of the form with ideals of teleology and normativity does not tally with the empirical evidence. Instead, he argues that the bildungsroman always produced 'cosmopolitan remainders' (p. 3) and that the logic of genre does not serve to stabilise nationalist ideologies so much as gesture toward the possibility of world literature. He also points out that literary critics find the teleology they interrogate for when they interpret the bildungsroman insofar as they fixate on the endings of novels and assume that this must be the real locus of meaning; in fact, the genre tends to understand human development in organicist terms, and has a rich repertoire of techniques for representing it as such.

\section{The Bildungsroman and/or the Novel of Disillusionment}

Most of the critical work discussed here treats the bildungsroman as a spurious apologia: it naturalises the way things are by presenting social orthodoxy as the getting of wisdom, the rich reward of growing up. At the same time, it is now conventional to admit that the affirmative, social-adjustment model of the bildungsroman is something of a critical mirage. The group of Victorian and early Edwardian novels routinely designated 'anti-bildungsromane', 'critiques' of the bildungsroman, bildungsromane of 'non-fulfilment', or 'meta-bildungsroman' (which includes Brontë's Villette [1853], Eliot's Mill on the Floss, Schreiner's Story of an African 
Farm, Hardy's Tess of the d'Urbervilles [1891] and Jude the Obscure, Wilde's Picture of Dorian Gray, Conrad's Lord Jim, and several Wells novels, though it might be expanded to include many less firmly canonical texts) is larger than the body of 'classic' bildungsroman (Brontë's Jane Eyre, Dickens's Great Expectations and David Copperfield, and Eliot's Middlemarch and Daniel Deronda). Even Eliot's Middlemarch is a problem case, and for the very reason Moretti exempted it from his general indictment of the English bildungsroman tradition: its real subjects are failure and disillusionment (216). The fact that 'classic' bildungsroman such as Jane Eyre and Daniel Deronda are by authors who also produced novels commonly celebrated as anti-bildungsroman (Villette and The Mill on the Floss) is suggestive of how the category is at risk of being overshadowed by its negations, especially since it is often argued that women writers like Brontë and Eliot necessarily have a fraught relationship with the ideal of bildung and thus with the form.

Etsy defends his own use of the classical bildungsroman model on the grounds that 'genres are almost always empty sets that shape literary history by their negation, deviation, variation' (p. 18). The invocation of 'literary history' here is slippery: Etsy is referring both to the influence of generic conventions on novelists and to the fact that the bildungsroman has been a 'recurrent object of [...] theoretical desire' (p. 18). But the problem is that the theoretical desire for the classical bildungsroman has only a tenuous connection to literary history, and this way of justifying its continued critical career repeats the conservative logic the genre is thought to embody: although nobody really believes in the existence of the classical bildungsroman, we need to keep affirming its value as a theoretical framework because it has been handed down to us. This logic also represses the question of whether critical preoccupation with the classical bildungsroman distorts our readings of nineteenth-century literature and culture. Isobel Armstrong's recent Novel Politics: Democratic Imaginations in Nineteenth Century Fiction (2017) suggests that it does: she argues it has helped to obscure the extent to which nineteenth-century novels participate in a democratic and egalitarian imaginary. She observes that the nineteenth century novels of 'dispossession and dereliction' are 'equally, if not more powerful' than the bildungsroman narrative of individual self-realisation, and reveal the capacity of the novel form to 'expose systemic inequity' (p. 19).

Lukács' Theory of the Novel (1914-15) is one of the key sources of the notion of the bildungsroman as a totalising genre of social integration. Yet Lukács acknowledged that in 'most individual cases the dividing line' between it and another type of novel, 'the novel of disillusionment', is 'fluid' (p. 136). This type of novel dramatises a 'profound dissonance between behaviour and soul, between outward destiny and inner fate' (p. 116). Although he does not explicitly invoke the 'Confessions' section of Wilhelm Meister or Hegel's discussions of the topic, his anatomy of the 'Novel of Disillusionment' resonates strongly with the 'Beautiful Soul' paradigm. Lukács conflates the novel of disillusionment with its protagonist, and suggests that they suffer equally from the malaise of Romantic solipsism: such novels have a 'contemplative' rather than an 'active' protagonist, and exhibit an 'over-intensified, over-determined desire for an ideal life as opposed to a real one, a desperate recognition of the fact that this desire is doomed to remain unsatisfied, a utopia based from the start on an uneasy conscience and the certainty of defeat' ( $p$. 
116). Lukács wrote Theory of the Novel prior to embracing Marxism and when he still thought that the Hegelian ideal of synthetic wholeness was the supreme test of aesthetic value. He thus valorises the bildungsroman and treats the novel of disillusionment as an inferior genre, one always on the verge of dissolving into incoherence, maudlin pessimism, or mere navel-gazing. Yet he nonetheless betrays an attraction to the kind of proto-modernist fragmentation and alienation embodied in the novel of disillusionment. He suggests that at its finest, this type of novel discovers profound meaning in failure:

By a strange and melancholy paradox, the moment of failure is the moment of value; the comprehending and experiencing of life's refusals is the source from which the fullness of life seems to flow. What is depicted is the total absence of any fulfilment of meaning, yet the work attains the rich and rounded fullness of a true totality of life (p.126)

Lukács is writing primarily in praise of Flaubert's L'Éducation sentimentale (1869), but the comment could serve as a beautiful gloss on Villette, Jude the Obscure, The Story of an African Farm, and probably many other novels currently labelled 'antibildungsroman' or modernist critiques of the form.

Jeffrey Sammons's 1981 call to restrict the usage of the term bildungsroman has obviously gone unheeded, and only inspired elaborate forms of critical selfconsciousness about the genre. Most of the work surveyed here relies on the classical definition because it is a standard against which to measure the critical force of a particular novel's depiction of bad education, blighted potential, or failure. In other words, critics remain attached to the classical bildungsroman because it seems like the ultimate genre of cruel optimism, to borrow Laurent Berlant's (2011) term: it signifies an ideal of human flourishing which can only be a destructive fantasy given the social conditions of the novel's protagonist. This model of the bildungsroman in turn enables critics to articulate why the negativity of a larger body of coming-of-age novels should be read as dissident and experimental. But what if we proceeded instead from the assumption that when Schreiner wrote Story of an African Farm or Hardy wrote Jude the Obscure, they imagined they were contributing to a rich tradition of novels of disillusionment and failure? We should retain the term bildungsroman - it seems too late to banish it - but recognise that it might refer to either an affirmative or profoundly negative coming-of-age narrative (or to an ambiguous composite of these alternatives), and that such novels may sustain or subvert dominant ideologies. Lukács did not attempt to theorise why the distinction between the affirmative, totalising bildungsroman and the novel of disillusionment is usually hard to discern, but doing so seems a much more interesting task for future scholars than continuing to pretend that the former type of novel tyrannised over the imaginations of nineteenth- and early twentieth-century writers. 


\section{REFERENCES}

Armstrong, I.(2017). . Novel Politics: Democratic Imaginations in NineteenthCentury Fiction. Oxford: Oxford University Press.

Bennett, K. L. (2014). Principle and Propensity: Experience and Religion in the NineteenthCentury British and American Bildungsroman. Columbia: University of South Carolina.

Berlant, L. (2011). Cruel Optimism. Durham: Duke University Press.

Boes, T. (2006).. 'Modernist Studies and the Bildungsroman: A Historical Survey of Critical Trends'. Literature Compass 3/2 (2006), 230-243.

Boes, T. (2012) . Formative Fictions: Nationalism, Cosmopolitanism, and the Bildungsroman. Ithaca: Cornell University Press.

Bogen, A. (2013). Women's University Fiction, 1880-1945. London: Pickering and Chatto.

Castle, G. (2006). Reading the Modernist Bildungsroman. Gainesville: University Press of Florida.

Cohn, E. (2015). Still Life: Suspended Development in the Victorian Novel. Oxford: Oxford University Press.

Dilthey, W. (1985). Poetry and Experience. (Eds) Rudolf A. Makkreel and Frithjof Rodi. New Jersey: Princeton University Press.

Eastham, A. (2011). Aesthetic Afterlives: Irony: Literary Modernity, and the Ends of Beauty. London: Continuum, 2011.

Ehnenn, J. (2017). 'Reorienting the Bildungsroman: Progress Narratives, Queerness, and Disability in The History of Sir Richard Calmady and Jude the Obscure'. Journal of Literary E Cultural Disability Studies 11.2, 151-168.

Etsy J. (2011). Unseasonable Youth: Modernism, Colonialism, and the Fiction of Development. New York: Oxford University Press.

Feder, H. (2014).. Ecocriticism and the Idea of Culture: Biology and the Bildungsroman. Farnham: Ashgate.

Gannon, C. (2014). 'Walter Besant's Democratic Bildungsroman'. Narrative 22.3, 372-394.

Gannon, C. (2015). . 'H. G. Wells and the Aestheticised Individual: Critiquing the Bildungsroman in The Bulpington of Blup'. Modern Philology 112.3, 503-521.

Hegel, G. W. F. (1977). Phenomenology of Spirit. Trans. A.V. Miller. Oxford: Oxford University Press.

Hegel, G. W. F. (1975). Aesthetics: Lectures on Fine Art. 2 vols., vol. II. Trans. T. M. Knox. Oxford: Clarendon Press.

Huffels, N. (2011). 'Tracing Traumatic Memory in The Woman in White: Psychic Shock, Victorian Science, and the Narrative Strategy of the ShadowBildungsroman'. Victorian Review 37.1, 42-61.

Jay, E. (2010).. 'Be Sure and Remember the Rabbits': Memory as Moral Force in the Victorian Bildungsroman', Literature and Theology 24.4, 360-377. 
Lukács, G. (1971).. Theory of the Novel. London: Merlin Press..

Milne, D. (2002).. 'The Beautiful Soul: From Hegel to Beckett', Diacritics 32.1, 65-80.

Moretti, F. (1987). The Way of the World: the Bildungsroman in the European Culture. London: Verso.

Nyman, J. (2009). Home, Identity, and Mobility in Contemporary Diasporic Fiction. Amsterdam: Rodopi.

Prewitt Brown, J. (2013).. 'The Moral Scope of the English Bildungsroman'. Oxford Handbook of the Victorian Novel. (Ed)Lisa Rodensky. Oxford University Press, 664-677.

Rosenthal, J. (2017).Good Form: the Ethical Experience of the Victorian Novel. Princeto: Princeton University Press, 2017.

Redfield, M. (1996). Phantom Formations: Aesthetic Ideology and the Bildungsroman. Ithaca: Cornell University Press.

Sammons, J. L. (1991). 'The Bildungsroman for Nonspecialists: An Attempt at Clarification'. Reflection and Action: Essays on the Bildungsroman (Ed) James N. Hardin. Columbia: University of South Carolina Press, 26-45.

Salmon, R. (2013). The Formation of the Victorian Literary Profession. Cambridge University Press..

Treagus, M. (2010).. Empire Girls: the Colonial Heroine Comes of Age. Adelaide: University of Adelaide Press.

Woloch, A. (2009). The One vs. the Many: Minor Characters and the Space of the Protagonist in the Novel. New Jersey: Princeton University Press, 2009.

Zwierlein, A. J. (2012).. 'The Biology of Social Class: Habit Formation and Social Stratification in Nineteenth-Century British Bildungsromane and Scientific Discourse'. Partial Answers 10.2, 335-360. 